Research Journal of Animal Sciences 4 (1): 5-9, 2010

ISSN: $1993-5269$

(C) Medwell Journals, 2010

\title{
Study of the PSE Expression in the Pectoralis Major Muscle of Three Genetic Lines of Turkeys
}

\author{
${ }^{1}$ H.P. Ngo, ${ }^{1}$ G. Abi-Rizk, ${ }^{2}$ T. Le Quang, ${ }^{3}$ M. Abou Ali, ${ }^{1}$ L. Aldebert and ${ }^{1}$ M. Franck \\ ${ }^{1}$ Laboratoire De Zootechnie, Universite de Lyon, \\ Ecole Nationale Veterinaire de Lyon, 69280 Marcy L'Etoile, France \\ ${ }^{2}$ UPSP 2007-03-135 RTI2B: Reparation Tissulaire, Interactions Biologiques et Biomateriaux, \\ Universite de Lyon, Ecole Nationale Veterinaire de Lyon, 69280 Marcy L'Etoile, France \\ ${ }^{3}$ Abattoir Corico, BP 9, Le Colombier 69860 Monsols, France
}

\begin{abstract}
The objectives of this study were to characterize the sensory and the technological quality of meat of three genetic lines of turkey (Hybride, Nicholas and BUT9). The muscle $\mathrm{pH}$ was measured at $15 \mathrm{mn}$ after slaughter ( $\mathrm{pH} 1$ ) and 5 h post-mortem $(\mathrm{pH} \mathrm{5)}$. The was measured on the pectoralis major muscle at the time of deboning. The $\mathrm{pH}$ results showed that the mean of $\mathrm{pH} 1$ was significantly higher for two groups of Nicholas and BUT9. For the $\mathrm{pH} 5 \mathrm{~h}$ post mortem, the differences were significant between three groups; the mean of $\mathrm{pH}$ of Hybride group was always highest. The colour observed had a significant difference between Nicolas and two others groups (Hybride and BUT9); however there was not significantly different between Hybride and BUT9. Consider the PSE problem in turkeys is similar to the pork, the fall of pH post-mortem and the meat colour can help us to conclude that the quality of the meat of Turkeys of the Nicholas group is better than the Hybrid and BUT9 groups.
\end{abstract}

Key words: PSE, $\mathrm{pH}$, colour, Turkey, meat quality, pectoralis major muscle, post-mortem

\section{INTRODUCTION}

Pale Soft Exudative (PSE) syndrome is always an important problem to meat quality which leads to a paler colour of meat, higher toughness and lower water holding capacity. In pork, PSE syndrome is a major industrial preoccupation because the cooked hams industries in France are supplied with at least $15-20 \%$ of PSE meat. Additionally, it is now well established that cooked hams manufactured from severe PSE meat may reached a $50 \%$ of financial losses (O'Neill et al., 2003).

In Turkey, some studies recently have found the PSE syndrome which were similar to these observed in pork (Penny, 1969; Warris and Brown, 1987). The PSE Turkey meat is pale in colur has lower water-holding capacity and forms softer gels (Barbut, 1993, 1997; McKee and Sams, 1997; McKee et al., 1998).

The demands of Turkey now-a-days were more and higher especially for the industry of processed cooked products. So the PSE Turkey meat problem was more important for the meat quality and it could be bad influenced during processing. Therefore, the objective of this study was to evaluate the quality of meat of three lines Turkey difference (Hybride, Nicholas and BUT9) with these parameters: the rate of $\mathrm{pH}$ fall post-mortem and the colour in Turkey breast meat.

\section{MATERIALS AND METHODS}

Animals: Three groups of Turkey (Hybride, Nicholas and BUT9) from 240-260 for each group were used in this study. All of birds were housed in three building of the same farmer in the region of Rhône (France) and slaughtered at 12 weeks old in the Corico slaughter (Monsols, France). The conditions of housing such as sanitary condition, environment, nutrition and water were similar for three groups.

All of birds were carried to the slaughter house on the same day after a night collection; about 10 Turkeys were packaged in one box and transported by car where the transport time from the farmer to the slaughter house would not be $>2 \mathrm{~h}$. At the slaughter house, the birds were allowed to rest for $1 \mathrm{~h}$ before being slaughtered. Then they were hung on shackles line and electrically stunned by placing their heads in a charged water bath. Immediately after stunning, birds were killed by bleeding through a unilateral neck cut.

Corresponding Author: H.P. Ngo, Laboratoire de Zootechnie, Ecole Nationale Veterinaire de Lyon, 1 Avenue Bourgelat, 69280 Marcy L'Etoile, France 


\section{Measurements}

pH: The muscle $\mathrm{pH}$ was measured at $15 \mathrm{mn}$ after slaughter ( $\mathrm{pH} 1)$ and $5 \mathrm{~h}$ post-mortem ( $\mathrm{pH} 5)$. On the other hand, the mean of rate of $\mathrm{pH}$ fall per hour for three groups of Turkey were calculated. The $\mathrm{pHs}$ were measured with a portable $\mathrm{pH}$ meter equipped with a xerolyte electrode $(\mathrm{pH}$ plus, Sydel).

Colour: The colour of meat was measured on the pectoralis major muscle at the time of deboning $(5 \mathrm{~h}$ post-mortem) by using a Minolta colourimeter CR 300 (Indice D 65). The colour was determined by using the CIELAB colour values for $L^{*}$, redness $\left(a^{*}\right)$ and yellowness $\left(b^{*}\right)$.

Statistical analysis: The experiment have 3 groups of Turkey; the main effects of $\mathrm{pH}$ and colour were analyzed by using the Analysis of Variance (ANOVA). Difference was considered significant if $\mathrm{p}<0.05$.

\section{RESULTS}

pH: The mean of pH1 for Hybride was 6.34 (SD 0.24); Nicholas $=6.26($ SD 0.23) and BUT9 $=6.23($ SD 0.24). These values were significantly different between the Hybride group and two other groups (Nicholas and BUT 9) but no significant difference were found between two groups Nicholas and BUT9 $(\mathrm{p}>0.05)$.

The significant differences were observed among 3 groups for the mean of $\mathrm{pH} 5$; Hybride $=6.08(\mathrm{SD} 0.19)$; Nicholas $=6.04($ SD 0.21) and BUT9 $=5.98($ SD 0.22) .

Colour: The values of lightness $\mathrm{L}^{*}$ for Hybride groups was 45.8 (SD 3.1); Nicholas $=44.1$ (SD 2.4) and BUT9 $=45.7$ (SD 3.1). Significant differences were observed between Nicolas and two others groups (Hybride and BUT9) but there was not significantly different between Hybride and BUT9.

For the Hybride groups, the value of redness $\left(a^{*}\right)$ was 4.2 (SD 0.9) and there were significantly differences between this group and Nicholas (4.5; SD 0.8) and BUT9 (4.4; SD 0.9). No significant difference between Nicholas and BUT9 groups were detected.

\section{DISCUSSION}

pH: The Pale Soft Exudative (PSE) syndrome was characterised by a paler colour, a lower water-holding capacity and an excessive hardness after cooking (Monin et al., 1999). Warris and Brown (1987) have

reported that the early post-mortem $\mathrm{pH}$ decline from $30 \mathrm{~min}^{-1} \mathrm{~h}$ was the most important factor which determined the degree of exudation in pork meat. So the rate of $\mathrm{pH}$ fall seemed to be the major factor which determined the severity of PSE meat. The relation between temperature and $\mathrm{pH}$ in the development of PSE characteristics was also important and well-established, the couples low pH-high temperature of carcass during the development of the rigor mortis involves the protein denaturation (Bendall and Wismer-Pedersen, 1962; Fernandez et al., 1994; Turkey: McKee et al., 1998; Molette et al., 2003; Alvarado and Sams, 2004).

In fact, Lawrie (1998) has showed that when the muscle was put simultaneously to a $\mathrm{pH}<6$ and a temperature $>35^{\circ} \mathrm{C}$, the denaturation of proteins would be maximum.

The $\mathrm{pH}$ results showed that the mean of $\mathrm{pH} 1$ was higher for two groups of Nicholas and BUT9. There was significantly different $(\mathrm{p}<0.05)$ between these two groups and the group of Hybride but no significant difference between Nicholas and BUT9 groups.

For the $\mathrm{pH} 5 \mathrm{~h}$ post-mortem, the difference were significant between three groups; the mean of $\mathrm{pH}$ of Hybride group was always highest: 6.08 (SD 0.19), meanwhile, the mean of $\mathrm{pH}$ of BUT9 group was lowest: 5.98 (SD 0.22)

In addition, the mean of rate of $\mathrm{pH}$ fall per hour for Hybride and BUT9 were 0.05 (SD 0.04); however for Nicholas was 0.04 (SD 0.04). No significant differences were detected among three groups (Table 1).

For the $\mathrm{pH}$ fall, the mean value in the Hybride was higher than two other groups. After $5 \mathrm{~h}$, this value was always highest in three groups but the noticed decrease of $\mathrm{pH} 1-\mathrm{pH} 5$ was 0.26 meanwhile 0.22 and 0.25 for Nicholas and BUT9 groups, respectively.

Couleur: The indicator role of colour in PSE poultry meat has been reported in a lot of previous study (Barbut, 1993, 1996, 1998; Woelfel et al., 2002). Indeed, a higher of L* value (lighter meat) was presented.

Moreover, Barbut $(1993,1996,1998)$ supposed to sort the pectoralis major muscle according to their $\mathrm{L}^{*}$ value with a limiting threshold of $\mathrm{L}^{*}>53$. Beyond this value, the meat will be considered PSE. However, Northcutt (1994)

Table 1: The values of $\mathrm{pH} \mathrm{1;} \mathrm{pH} 5 \mathrm{~h}$ and the rate of $\mathrm{pH}$ fall of three groups of Turkey: Hybride, Nicholas and BUT9 $($ Mean \pm SD)

\begin{tabular}{lcccc}
\hline Dindes & $\mathrm{n}$ & $\mathrm{pH} \mathrm{1}$ & $\mathrm{pH} \mathrm{5} \mathrm{h}$ & $\begin{array}{c}\text { Rate of } \mathrm{pHfall/h} \\
\text { (unit of } \mathrm{pH} \text { ) }\end{array}$ \\
\hline Hybride & 248 & $6.34 \pm 0.24^{\mathrm{a}}$ & $6.08 \pm 0.19^{\mathrm{c}}$ & $0.05 \pm 0.04^{\mathrm{f}}$ \\
Nicholas & 242 & $6.26 \pm 0.23^{\mathrm{b}}$ & $6.04 \pm 0.21^{\mathrm{d}}$ & $0.04 \pm 0.04^{\mathrm{f}}$ \\
BUT9 & 256 & $6.23 \pm 0.24^{\mathrm{b}}$ & $5.98 \pm 0.22^{\mathrm{e}}$ & $0.05 \pm 0.04^{\mathrm{f}}$ \\
\hline a-f. Means within a column with no common superscript differ significantly \\
(p<0.05)
\end{tabular}


Table 2: The values of the colour of three groups of Turkey: Hybride, Nicholas and BUT9 $($ Mean \pm SD)

\begin{tabular}{llccc}
\hline Dindes & $\mathrm{n}$ & $\mathrm{L}^{*}$ & $\mathrm{a}^{*}$ & $\mathrm{~b}^{*}$ \\
\hline Hybride & 333 & $45.8 \pm 3.1^{\mathrm{a}}$ & $4.2 \pm 0.9^{\mathrm{c}}$ & $0.0 \pm 0.80^{\mathrm{e}}$ \\
Nicholas & 327 & $44.1 \pm 2.4^{\mathrm{b}}$ & $4.5 \pm 0.8^{\mathrm{d}}$ & $-0.1 \pm 0.6^{\mathrm{e}}$ \\
BUT9 & 365 & $45.7 \pm 3.1^{\mathrm{a}}$ & $4.4 \pm 0.9^{\mathrm{d}}$ & $0.5 \pm 1.00^{\mathrm{f}}$ \\
\hline
\end{tabular}

a-f. Means within a column with no common superscript differ significantly $(\mathrm{p}<0.05)$

sorted the pectoralis major muscle of Turkey according to $\mathrm{L}^{*}$ value at $24 \mathrm{~h}$ post-mortem but they can not reach to highlight in the modification of meat quality.

In the study, the mean of $\mathrm{L}^{*}$ value was 45.54 (SD 4.24) for Hybride and 45.72 (SD 3.07) for BUT9 which were higher than Nicholas group: 44.09 (SD 2.37) (Table 2).

The mean value of Nicholas group was 1-2 points lower than two other groups with a significant difference between Nicholas and two other groups $(\mathrm{p}<0.05)$ but no significant difference for the $\mathrm{L}^{*}$ value between Hybride and BUT9 groups.

In pork, two categories of meats with a less quality related to the acceleration rate of $\mathrm{pH}$ fall post mortem have been presented by many researchs (Van Laack et al., 1994; Warner et al., 1997; Cheah et al., 1998; Joo et al., 1999; Moya et al., 2001).

In Turkey, the results was inverse (Froning et al., 1978; Northcutt, 1994; Pietrzak et al., 1997; McKee and Sams, 1997; Rathgeber et al., 1999; Fernandez et al., 2001; Hahn et al., 2002; Soares et al., 2003; Alvarado and Sams, 2004). Indeed, when Turkeys were placed in the conditions of acute thermal stress just before slaughter, the $L^{*}$ values of meat were not different (Turkey: Northcutt, 1994; Owens et al., 2000) or higher (Turkey: Froning et al., 1978); or lower (chicken: Soares et al., 2003) in the stressed animals to compare with the unstressed animals. When Turkeys were selected according to the early $\mathrm{pH}$ value (15-20 min post-mortem), Pietrzak et al. (1997) and Fernandez et al. (2001) highlighted a higher values of $L^{*}$ for the meat of the GR to compare to the GN Turkeys.

The increase in the values of $\mathrm{L}^{*}$ observed in the PSE meats was generally related with a post-mortem glycolysis accelerated (McKee and Sams, 1997; Pietrzak et al., 1997) which could be explained the differences in rate of $\mathrm{pH}$ fall.

In the research, if only $\mathrm{L}^{*}$ value is considered the for the PSE meats judgment such as done in the pork, the Nicholas group presents a clearly superior to compare with two other groups. According to Bendall and Wismer-Pedersen (1962), the differences in $\mathrm{L}^{*}$ value related to the proteins denaturation and more specifically for the sarcoplasmic proteins because this protein led to a more important reflection of the light (light scattering).
For $a^{*}$ value, the results of bibliography were rather variable. In the study of Pietrzak et al. (1997), the values of $\mathrm{a}^{*}$ were not different between GR and GN. However, Froning et al. (1978) have proven that the value of $\mathrm{a}^{*}$ were higher for the stressed animals by the heat just before slaughter.

Moreover, Rathgeber et al. (1999), Fernandez et al. (2002), Hahn et al. (2002) in Turkey and Joo et al. (1999), in pork reported that $\mathrm{a}^{*}$ values were higher for PSE meats than the normal one. For that, an increasing on the $\mathrm{a}^{*}$ value can be assigned and were done by an concentration of this pigment in the muscle following the leak of aqueous diluents.

In the study, the red index $\left(\mathrm{a}^{*}\right)$ was significantly higher for the Nicholas than two groups of Hybride and BUT9 $(\mathrm{p}<0.05)$. But there was not significantly difference between Hybride and BUT9 groups. That means the meats of Nicholas groups were redder than two other groups.

The yellow index $\left(b^{*}\right)$, the 3rd component of the Lab system was generally not exploited for the characterization of PSE meat like in the pork or in the poultry because of the low variability of its value but Franck et al. $(1999,2000)$ showed the interest of the b* value which varies in the same direction with $L^{*}$. In the meat generally, the value of $b^{*}$ strongly increases between the slaughter day and the 3rd day conservation of the meat (Sante, 1993).

We found that the yellow index $\left(b^{*}\right)$ was significantly higher in the BUT9 groups to compare with the two other groups $(\mathrm{p}<0.05)$. But there was not significant difference between Hybride and Nicholas groups.

The previous study in the pork showed that the $\mathrm{pH}$ excepting the $\mathrm{pH} 1$ was not the prediction value; if we continue this way, The $\mathrm{L}^{*}$ value in Turkey give the best results and Nicholas group have a highest quality of meat.

\section{CONCLUSION}

The objectives of this study were to characterize the sensory and the technological quality of meat of three genetic lines of Turkey thanks to the values of $\mathrm{pH}$ at the time of slaughter, $\mathrm{pH} 5 \mathrm{~h}$ post-mortem and the colour of pectoralis major muscle.

During this study, The fall speed of $\mathrm{pH} 5 \mathrm{~h}$ postmortem of Nicholas Turkeys group were less important to compare to the Hybrid or BUT9 group. Moreover, the pale colour of meat was mainly used to describe the PSE meats. In the study, the colours values of three groups of Turkeys has evalualedand the results showed that the meat colour of Nicholas group were less pale than the Hybride and BUT9 groups. 
If the PSE problem in Turkeys is similar to the pork, the fall of $\mathrm{pH}$ post-mortem and the meat colour can help us to conclude that the quality of the meat of Turkeys of the Nicholas group is better than the Hybrid and BUT9 groups.

\section{REFERENCES}

Alvarado, C.Z. and A.R. Sams, 2004. Turkey carcass chilling and protein denaturation in the development of pale, soft and exudative meat. Poult. Sci., 83: 1039-1046.

Barbut, S., 1993. Colour measurements for evaluating the pale soft exudative (PSE) occurence in turkey meat. Food Res. Int., 26: 39-43.

Barbut, S., 1996. Estimates and detection of the PSE problem in young Turkey breast meat. Can. J. Anim. Sci., 76: 455-457.

Barbut, S., 1997. Problem of pale, soft exudative meat in broiler chickens. Br. Poult. Sci., 38: 355-358.

Barbut, S., 1998. Estimating the magnitude of the PSE problem in poultry. J. Muscle Foods, 9: 35-49.

Bendall, J.R. and J. Wismer-Pedersen, 1962. Some properties of the fibrillar proteins of normal and watery pork muscle. J. Food Sci., 27: 144-159.

Cheah, K.S., A.M. Cheah and A. Just, 1998. Identification and characterization of pigs prone to producing RSE (reddish-pink, soft and exudative) meat in normal pigs. Meat Sci., 48: 249-255.

Fernandez, X., A. Torslid and E. Tornberg, 1994. The effect of high post-mortem temperature on the development of pale, soft and exudative pork: Interaction with ultimate $\mathrm{pH}$. Meat Sci., 37: 133-147.

Fernandez, X., V. Sante, E. Baeza, E.L. Bihan-Duval and C. Berri et al., 2001. Post mortem muscle metabolism and meat quality in three genetic types of Turkey. Br. Poult. Sci., 42: 462-469.

Fernandez, X., V. Sante, E. Baeza, E.L. Bihan-Duval and C. Berri et al., 2002. Effects of the rate of muscle post mortem $\mathrm{pH}$ fall on the technological quality of Turkey meat. Br. Poult. Sci., 43: 245-252.

Franck, M., G. Benard, X. Fernandez, S. Barbry and P. Durand et al., 1999. Observations preliminaires sur le jambon destructure, description du phenomène et etude de quelques facteurs de variation. Journees Recherche Porcine France, 31: 331-338.

Franck, M., P. Figwer and M.T. Poirel, 2000. Effet du type genetique et du temps d'attente sur la frequence du caractere destructure de la viande de porc. C.R. des 8eme Journees des Sciences du Muscle et Technologies de la Viande, Paris, pp: 51-53.
Froning, G.W., A.S. Babji and F.B. Mather, 1978. The effect of preslaughter temperature. Stress, struggle and anesthetization on color and textural characteristic of turkey muscle. Poult. Sci., 57: 630-633.

Hahn, G., M. Malenica and W. Branscheid, 2002. The relationship between $\mathrm{pH}$ decline post-mortem and biochemical and physico-chemical properties of Turkey breast meat. Archiv Geflugelkunde, 65: 7-7.

Joo, S.T., R.J. Kauffman, B.C. Kim and G.B. Park, 1999. The relationship of sarcoplasmic and myofibrillar portein solubility to colour and water-holding capacity in porcine longissimus muscle. Meat Sci., 52: 291-297.

Lawrie, R.A., 1998. Lawries Meat Science. 6th Edn., Pergamon Press and Woodhead Publishing Ltd., New York, ISBN: 1-85573-395-1, pp: 212-226.

McKee, S.R. and A.R. Sams, 1997. The effect of seasonal heat stress on rigor development and the incidence of pale, exudative turkey meat. Poult. Sci., 76: 1616-1620.

McKee, S.R., B.M. Hargis and A.R. Sams, 1998. Pale, soft and exudative meat in turkeys treated with succinylcholine. Poult. Sci., 77: 356-360.

Molette, C., H. Remignon andR. Babile, 2003. Maintaining muscles at a high post-mortem temperature induces PSE-like meat in Turkey. Meat Sci., 63: 525-532.

Monin, G., C. Larzul, L.P. Roy, J. Culioli and J. Mourot et al., 1999. Effects of the halothane genotype and slaughter weight on texture of pork. J. Anim. Sci., 77: 408-415.

Moya, V.J., M. Flores, C. Aristoy and F. Toldra, 2001. Evolution of hydrophobic polypeptides during the ageing of exudative and non-exudative pork meat. Meat Sci., 57: 395-401.

Northcutt, J.K., 1994. Influence of antemortem treatment on post mortem muscle properties of poultry meat. Ph.D. Thesis, North Carolina State University, Raleigh, US, pp: 162.

O'Neill, D.J., P.B. Lynch, D.J. Troy, D.J. Buckley and J.P. Kerry, 2003. Effects of PSE on the quality of cooked hams. Meat Sci., 64: 113-118.

Owens, C.M., N.S. Matthews and A.R. Sam, 2000. The use of halothane gas to identify turkeys prone to developing pale, exudative meat when transported before slaughter. Poult. Sci., 79: 789-795.

Penny, I.F., 1969. Protein denaturation and water-holding capacity in pork muscle. Int. J. Food Sci. Technol., 4: 269-273.

Pietrzak, M., M.L. Greaser and A.A. Sosnicki, 1997. Effect of rapid rigor mortis processes on protein functionnality in pectoralis major muscle of domestic turkeys. J. Anim. Sci., 75: 2106-2116.

Rathgeber, B.M., J.A. Boles and P.J. Shand, 1999. Rapid postmortem $\mathrm{pH}$ decline and delayed chilling reduce quality of turkey breast meat. Poult. Sci., 78: 477-484. 
Sante, V., 1993. Instabilite de la couleur de la dinde (Meleagris gallopovo): Influence de la rigor mortis, du mode de conditionnement et d'antioxydants. Ph.D. Thesis, Universite Blaise Pascal, Clermont-Ferrand, France, pp: 132.

Soares, A.L., E.I. Ida, S.M. Miyamoto, F.J. HernandezBlazquez, R. Olivo, J.W. Pinheiro and M. Shimokomaki, 2003. Phospholipase A2 activity in poultry PSE, pale, soft, exudative, meat. J. Food Biochem., 27: 309-320.

Van Laack, R.L.J.M., R.G. Kauffman, W. Sybesma, F.J.M. Smulders, G. Eikelenboom and J.C. Pinheiro, 1994. Is colour brightness ( $L$-value) a reliable indicator of water-holding capacity in porcine muscle?. Meat Sci., 38: 193-201.
Warner, R.D., R.G. Kauffman and M.L. Greaser, 1997. Muscle protein changes post-mortem in relation to pork quality traits. Meat Sci., 45: 339-352.

Warris, P.D. and S.N. Brown, 1987. The relationships between initial $\mathrm{pH}$, reflectance and exudation in pig muscle. Meat Sci., 20: 65-74.

Woelfel, R.L., C.M. Owens, E.M. Hirschler, R. MartinezDawson and A.R. Sams, 2002. The characterization and incidence of pale, soft and exudative broiler meat in a commercial processing plant. Poult. Sci., 81: 579-584. 